\title{
Complete dissection of left anterior descending artery in a young woman after myocardial infarction
}

Całkowite rozwarstwienie gałęzi przedniej zstępującej lewej tętnicy wieńcowej u młodej kobiety po zawale serca

\author{
Hakan Özhan', Serkan Bulur², Osman Kayapınar ${ }^{3}$ Yasin Türker ${ }^{1}$ \\ ${ }^{1}$ Department of Cardiology, Duzce University, Duzce Medical School, Konuralp, Duzce, Turkey \\ 2Department of Cardiology, Istanbul Medeniyet University, Goztepe Training and Research Hospital, Kadikoy, Istanbul, Turkey \\ ${ }^{3}$ Department of Cardiology, Nallihan State Hospital, Nallihan, Ankara, Turkey
}

Postep Kardiol Inter 2012; 8 , 3 (29): 258-260

DOI: $10.5114 /$ pwki.2012.30408

\begin{abstract}
Spontaneous coronary artery dissection (SCAD) is a rare clinical condition that causes acute coronary syndrome and sudden cardiac death. Herein, we report a case of left anterior descending artery dissection after myocardial infarction. On the third day of myocardial infarction after successful thrombolysis, the patient had recurrent chest pain without any ST wave elevation. She was referred to our clinic for coronary angiography which showed completely dissected left anterior descending (LAD) artery. She was referred to a tertiary centre with intravascular ultrasonography (IVUS) capability. Her control angiogram showed restored flow with only minimal dissection (so IVUS was not performed) in the mid LAD. The lesions in the distal and mid LAD were stented. The final angiogram showed TIMI-III flow. Percutaneous coronary intervention is the first choice of treatment in patients with single-vessel spontaneous coronary artery dissection with ongoing signs of ischemia.
\end{abstract}

Key words: coronary dissection, myocardial infarction

\section{Streszczenie}

Samoistne rozwarstwienie tętnicy wieńcowej (spontaneous coronary artery dissection - SCAD) jest rzadką sytuacją kliniczną mogącą prowadzić do wystąpienia ostrego zespołu wieńcowego i nagłego zgonu sercowego. Poniżej przedstawiono opis przypadku rozwarstwienia gałęzi przedniej zstępującej (left anterior descending - LAD) lewej tętnicy wieńcowej po zawale serca. W trzecim dniu zawału serca leczonego skutecznie trombolitycznie u pacjentki wystąpił nawrót bólu w klatce piersiowej bez zmian odcinka ST. Chorą skierowano do ośrodka autorów w celu wykonania koronarografii, w której wykazano całkowite rozwarstwienie LAD. Pacjentkę przekazano do ośrodka trzeciego stopnia referencyjności dysponującego ultrasonografią wewnątrzwieńcową (intravascular ultrasonography - IVUS). Kontrolne badanie koronarograficzne uwidoczniło powrót przepływu w tętnicy z jedynie niewielkim rozwarstwieniem w środkowym odcinku LAD (w związku z tym nie wykonywano IVUS). W miejsce zmian w początkowym i środkowym odcinku LAD wszczepiono stenty. W końcowym angiogramie obserwowano przepływ TIMI 3. Przezskórna interwencja wieńcowa stanowi postępowanie z wyboru u chorych z jednonaczyniowym SCAD i utrzymującymi się oznakami niedokrwienia mięśnia sercowego.

Słowa kluczowe: rozwarstwienie tętnicy wieńcowej, zawał serca

\section{Introduction}

Spontaneous coronary artery dissection (SCAD) is a rare clinical condition that causes acute coronary syndrome (ACS) and sudden cardiac death. It is commonest in the fifth decade, with a striking female predominance, particularly occurring in the peripartum period [1]. Oral contraceptive use, heavy exercise, sexual intercourse, isolated fibromuscular dysplasia, blunt chest trauma, drug use, immunosuppression, Marfan and Ehlers-Danlos syndromes, and some inflammatory diseases have been shown to be associated with SCAD [1, 2].

\section{Corresponding author/Adres do korespondencji:}

Yard. Doç. Dr. Serkan Bulur MD, S.B. İstanbul Medeniyet Üniversitesi, Göztepe Eğitim ve Araștırma Hastanesi, Kardiyoloji A.D., Göztepe, ìstanbul, Turkey, tel.: 053338639 84, e-mail: drserkanbulur@yahoo.com

Praca wptynęła: 9.04.2012, przyjęta do druku: 3.08.2012. 


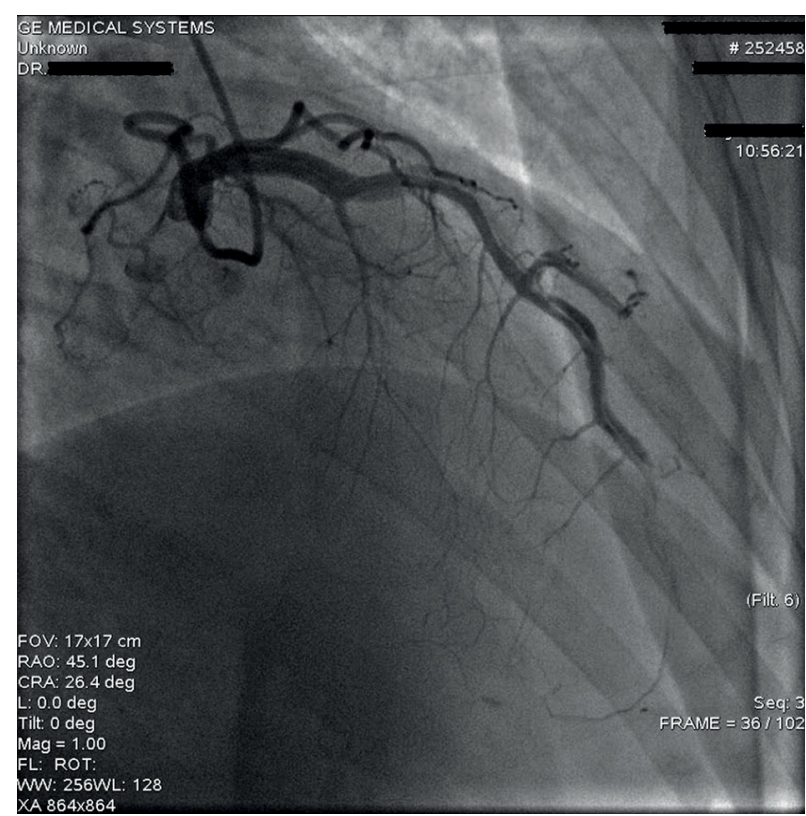

Fig. 1. Coronary angiography showing completely dissected left anterior descending artery

Ryc. 1. Koronarografia z widocznym catkowitym rozwarstwieniem gatęzi przedniej zstępującej lewej tętnicy wieńcowej

\section{Case report}

Herein, we report a case of left anterior descending artery dissection after myocardial infarction. A 40-year-old woman had been admitted to a peripheral hospital with prolonged chest pain. She had no history of previous cardiovascular disease, no collagen tissue disease and no risk factors for coronary artery disease. The electrocardiogram (ECG) on admission showed ST segment elevations in the anterior leads. Initial laboratory tests including complete blood count, electrolytes, and renal and liver functions were within normal limits. She was diagnosed with acute anterior myocardial infarction and alteplase treatment was started immediately. After thrombolysis her chest pain and ST wave elevations were resolved. On the third day of myocardial infarction the patient had recurrent chest pain without any ST wave elevation. She was referred to our clinic for coronary angiography which showed completely dissected left anterior descending (LAD) artery. Contrast medium was entrapped all the way down the artery (Figure 1). The true and false lumens were not clearly distinguishable so percutaneous coronary intervention was delayed. She was referred to a tertiary centre with intravascular ultrasonography (IVUS) capability. Her angiographic control one month later showed restored flow with only minimal dissection in the mid LAD (Figure 2). The lesions in the distal and mid LAD were stented with drug-eluting stents $(3.0 \mathrm{~mm} \times 15 \mathrm{~mm}$ and $3.5 \mathrm{~mm}$ $\times 18 \mathrm{~mm}$ BioMatrix, respectively). The final angiogram showed TIMI-III flow (Figure 3).

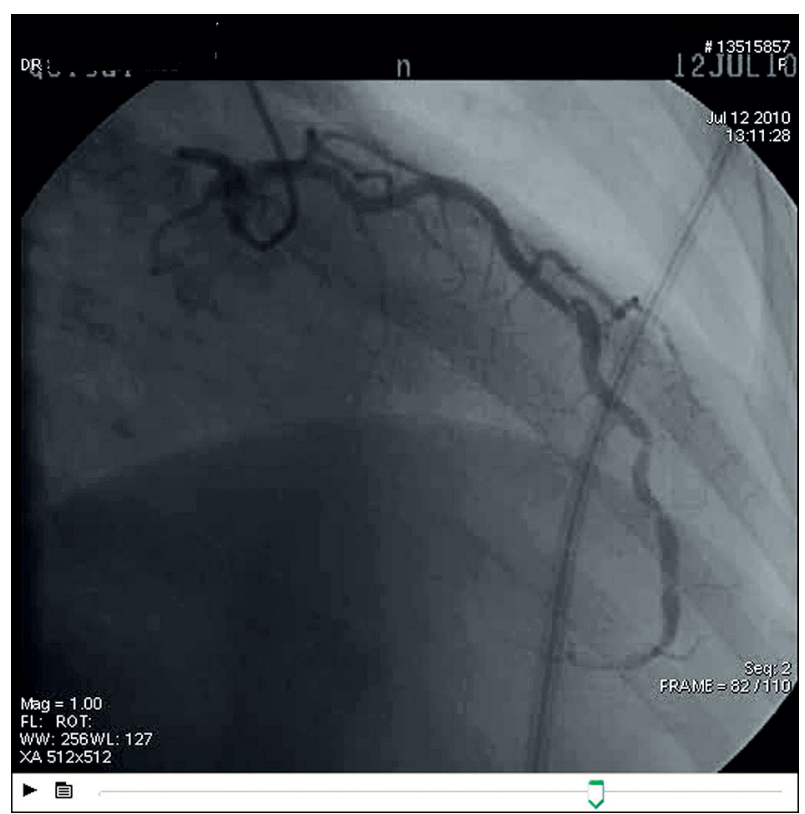

Fig. 2. Angiographic control 1 month later before stenting

Ryc. 2. Kontrola angiograficzna wykonana 1 miesiąc po wszczepieniu stentu

\section{Discussion}

The present case is unique in showing entire dissection of the LAD artery. The presentation is also interesting since it possibly arose on the third day of myocardial infarction. Presence of SCAD on admission is unlikely since

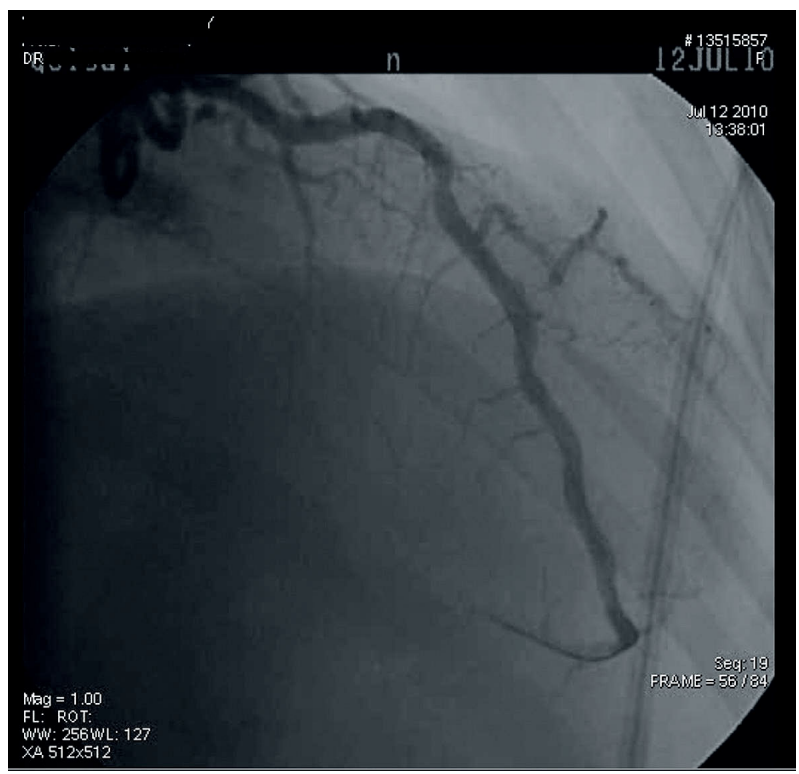

Fig. 3. Final angiogram showing TIMI-III flow after stenting the dissection

Ryc. 3. Końcowy angiogram po stentowaniu rozwarstwienia dokumentujacy przeptyw TIMI 3 
the patient had relief of her angina after thrombolysis and there was restoration of ST wave elevation. Although dissolving of the thrombi in the false lumen and lessening of compression of the true lumen and facilitating re-establishment of flow has been suggested [3], there is a paradox in its clinical setting since coronary artery dissections generally result in ST elevation myocardial infarction (STEMI) leading to thrombolytic use which results in propagation of the dissection. Stenting was unsuitable in very long dissections especially arising from the ostium, carrying a risk of stenting the false lumen.

The prognosis is poor in cases with SCAD. Although SCAD usually presents with symptoms of myocardial ischemia, it may also present with cardiogenic shock or sudden death. However, short-term mortality following SCAD is higher than with acute coronary syndromes and STEMI [3]. There is considerable controversy regarding the optimal management of patients with SCAD-related myocardial ischemia. Therapeutic approaches include conservative medical therapy, coronary artery bypass graft surgery and percutaneous coronary intervention (PCI). Medical treatment can be considered in asymptomatic patients. Jorgensen et al. [4] followed up 10 cases of coronary artery dissection presenting with acute myocardial infarction. Seven of them showed improvement and were followed with medical treatment and 3 patients underwent intervention. Successful surgical myocardial revascularization has been reported in multivessel dissections, SCAD involving the left main coronary artery and when $\mathrm{PCl}$ has failed. The $\mathrm{PCl}$ on the other hand is the treatment of choice in patients with single-vessel SCAD with ongoing signs of ischemia. Stenting is effective in pinning back the dissection flap. The issue whether the whole dissection should be covered or just the inlet of the intimal tear has not been resolved yet.

\section{References}

1. Kamineni R, Sadhu A, Alpert JS. Spontaneous coronary artery dissection: Report of two cases and 50-year review of the literature. Cardiol Rev 2002; 10: 279-284.

2. Basso C, Morgagni GL, Thiene G. Spontaneous coronary artery dissection: a neclected cause of myocardial ischemia and sudden death. Heart 1996; 75: 451-454.

3. Thompson EA, Ferraris S, Gress T, Ferraris V. Gender differences and predictors of mortality in spontaneous coronary artery dissection: a review of reported cases. J Invasiv Cardiol 2005; 17: 59-61.

4. Jorgensen MB, Aharonian V, Mansukhani P, Mahrer PR. Spontaneous coronary dissection: a cluster of cases with this rare finding. Am Heart J 1994; 127: 1382-1387. 